\title{
Social Responsibility Disclosure, Corporate Governance and Cost of Equity Capital
}

\author{
I Made Pradana Adiputra ${ }^{1 *}$, Sylvia Veronica Siregar ${ }^{1}$, Ratna Wardhani ${ }^{1}$ \\ ${ }^{1}$ Faculty of Economics and Business, Universitas Indonesia, Depok 16424, Indonesia \\ *adiputraundiksha@gmail.com
}

\begin{abstract}
This study aims to examine whether social responsibility disclosure positively affects the cost of equity capital in the previous year and to test whether social responsibility disclosure negatively affects the cost of equity capital in companies with good corporate governance. The approach is based on empirical research, drawing on data from annual sustainability reports published between 2012 to 2014 using 53 sample companies listed on IDX in accordance with GRI disclosure criteria for content analysis. CSR score calculation and regression analysis techniques were used for hypothesis testing with multivariate analysis. The findings confirmed that the influence of social responsibility disclosure was positively related to the cost of equity capital in the previous year and social responsibility disclosure negatively affected the cost of equity capital in firms with good corporate governance. These findings expand on empirical research related to CSR and corporate governance on the cost of equity capital using GRI4 and corporate governance scores in Indonesia context.
\end{abstract}

Keywords: Social Responsibility Disclosure, Corporate Governance, Cost of Equity Capital

\section{INTRODUCTION}

Profit-oriented business activities have a negative impact on society and lead to concrete environmental problems. In general, this is due to investors being more interested in implementing good environmental management and environmental problem like pollution ${ }^{1}$. Empirically tested an increase in CSR activities by firms around the world in relation to the performance of CSR in large firms and the increased willingness of firms to voluntarily report their CSR activities independently (standalone) ${ }^{2}$. Since the mid-1990s, an increasing number of firms worldwide have begun to disclose non-financial information related to social issues, such as environmental conservation, human rights protection, employee welfare improvement, and contributions to communities and societies $^{3}$.

The concept of corporate social responsibility (CSR) should be incorporated within a corporate strategy that focuses on environmental influences on people's living conditions, sensible behavior, and ethics in business ${ }^{4}$. In the last few decades, firms have spent money to understand whether CSR relates to firm performance ${ }^{4}$.

A negative relationship exists between the level of corporate social responsibility disclosure and cost of equity capital $^{5}$. Potential benefits from high corporate social responsibility disclosure include attracting investors and reducing the risk of estimating and asymmetric information that would reduce the cost of equity capital ${ }^{6}$. Social responsibility firms and CSR performance was negatively related to cost of equity capital ${ }^{2,7}$. Social responsibility disclosure of firms was negatively related to the cost of equity capital in countries or firms with either a stakeholder orientation or with high financial opaqueness (low financial transparency) ${ }^{3}$.

Furthermore, the results of this study suggest that the relationship between CSR and financial performance is still unknown ${ }^{4}$. The literature has shown that financial transparency may affect the cost of equity capital ${ }^{8}$, which is interesting when considering how financial disclosures and non-financial disclosures interact to influence the cost of equity capital ${ }^{3}$.

This research is based on previous studies ${ }^{2,3}$ that examined the effect of corporate social responsibility disclosure on the cost of equity capital. The difference between this study and previous studies is that it measures the level of corporate social responsibility disclosure by using broader content analysis, using instruments in the Global Reporting Initiative (GRI) 4. A survey conducted by KPMG found that the number of firms that include corporate social responsibility disclosure in their annual financial reports increased from 20 percent in 2011 to 51 percent in $2013^{9}$, Firms that use the Global Reporting Initiative (GRI) as a guide to disclose CSR increased from 69 percent in 2011 to 78 percent in 2013. This is what distinguishes the measurement of corporate social responsibility disclosure conducted by using a dummy for standalone CSR report ${ }^{2,3}$.

This study also includes corporate governance variables proxied with a broader corporate governance index, used to examine aspects of financial transparency within the scope of the firms ${ }^{3}$. Corporate governance is a set of 
mechanisms that direct and control a firm so that the firm's operations run in line with the expectations of the stakeholders. Corporate governance is also a mechanism of monitoring the activities of the firms so that the agent's actions adhere to the principal of increasing the value of the firm.

The purpose of research is: (1). to examine the whether corporate social responsibility disclosure affects the cost of equity capital in the previous year. (2). to examine whether social responsibility disclosure affects the cost of equity capital in firms with good corporate governance.

\section{LITERATURE REVIEW AND HYPOTHESIS DEVELOPMENT Agency Theory}

Agency relationship as a contract between one or more principals that asks an agent to perform some services for purposes that incorporate the delegation of some decision-making authority to an agent ${ }^{10}$. In contracts between managers and shareholders, managers are seen as agents and shareholders are seen as principals. Appropriate contracting to align the interests of agents and owners in the event of a conflict of agency theory ${ }^{11}$.

\section{Stakeholder Theory}

Stakeholder theory is used as a basis for analyzing the group to whom the firm should be responsible. Firms need support from stakeholders to continue their existence, therefore the success of the firms depend on the success of management in managing relationships with its stakeholders ${ }^{12,13}$. Stakeholder theory emphasizes organizational accountability far beyond financial or economic performance ${ }^{14}$. This theory states that organizations will voluntarily disclose information about their environmental, social performance, beyond and above mandatory requests, to meet actual or recognize expectations by stakeholders.

\section{Legitimacy Theory}

The theory of legitimacy suggests that organizations continually seek ways to ensure their operations are within the limits and norms prevailing in society ${ }^{14}$. The perspective of legitimacy theory, a firm will voluntarily report its activities if management considers that this is what the community expects ${ }^{14}$. Through disclosure in corporate reports, organizations may use disclosure to demonstrate management's concern for social value or to redirect the community's attention to the existence of the negative effects of organizational activity ${ }^{15}$.

\section{Corporate Social Responsibility Disclosure}

Definition of Corporate Social Responsibility according to the World Business Council for Sustainable Development (WBCSD) is a continuing commitment by businesses to act ethically and contribute to the economic development of local communities and society at large, together with improving living standards Workers and their whole family ${ }^{16}$. A typical CSR report contains a wealth of information, such as expenditures related to environmental protection and climate change, charitable contributions, and employee benefits - all of which are not normally reported in the financial statements but have significant implications for firm value ${ }^{3}$. Some CSR projects directly imply positive cash flows for the firm's future ${ }^{2}$. Encourages firms to start adopting the Sustainability Reporting Guidelines (SRG) of the Global Reporting Initiative (GRI) due to lack of guidance from the government and the Indonesian Institute of Accountants. GRI provides a comprehensive guide for firms in reporting information related to cost, and economic, environmental, and social performance ${ }^{17}$.

\section{Cost of Equity Capital}

The cost of equity capital is defined as cost incurred to finance the source of funding ${ }^{18}$. Another definition stated that cost of equity capital is a discount rate calculation imposed on a firm's shares by market participants on the basis of its future cash flow forecast to determine the current share price ${ }^{19}$. In the literature has shown that financial transparency may affect the cost of equity capital ${ }^{8}$, it is naturally interesting to examine how financial and nonfinancial disclosures interact in influencing the cost of equity capital ${ }^{3}$.

\section{Corporate Governance}

Corporate governance is a mechanism used to ensure that the fund owner, such as the shareholder or lender, of the firm receives a return from the activities run by the manager, or in other words, how the owner of the fund exercises control against managers ${ }^{20}$. Corporate governance mechanisms are created by shareholders to encourage effective and efficient enterprise management and to provide some control over some decisions made by managers ${ }^{21}$. Some examples of the measurements of corporate governance that have been undertaken are based on: institutional ownership in the US, ${ }^{22}$; non-executive directors and institutional ownership in the UK (Wahab and Holland, 2012); family versus non-family in Indonesia ${ }^{23}$; dual CEOs, size boards, and independent directors in Tunisia $^{24}$; and the effectiveness of the board of commissioners and of the audit committee in monitoring the firm's 
operations in Indonesia ${ }^{25}$.

\section{Hypothesis Development}

There is a positive relationship between disclosure of corporate social responsibility and the cost of equity capital in the previous year ${ }^{2}$. However in a stakeholder-oriented country, disclosure of corporate social responsibility is negatively related to the cost of equity capital ${ }^{3}$. In agency theory, the disclosure of corporate social responsibility will reduce agency conflict, resulting in reduced agency costs and information asymmetry. Additionally, $\mathrm{n}$ stakeholder theory, claiming corporate social responsibility helps to satisfy not only shareholder interest but also interests of other stakeholders such as employees, customers, suppliers, creditors, and society. According to the theory of legitimacy, a firm will voluntarily report its activities if management believes that it is what the community expects. Based on the results of these theoretical studies the following hypothesis can be formulated:

$\mathbf{H}_{1}$ : Corporate social responsibility disclosure is positively related to the cost of equity capital in the previous year.

There is a negative relationship between corporate social responsibility disclosure and the cost of equity capital in a country or firm with a higher level of financial blurriness ${ }^{3}$. A number of studies found a significant negative relationship between financial transparency and the cost of equity capital in the US ${ }^{5,26}$. The relationship between error estimates and disclosure of corporate social responsibility is more negative in firms and countries with less transparent financial conditions which thereby impact the cost of equity capita ${ }^{27}$. Corporate governance structures that deal with foreign and government stock ownership and financial distress directly influence the corporate social responsibility disclosure ${ }^{28}$. In agency theory, the separation between management and the owner of the firm results in a principal-agent relationship. It is necessary to align the interests of the agents and owners in order to avoid conflicts of interest. In stakeholder theory, the stakeholder can control or influence the firm's resources. Legitimacy theory explicates a social contract that explains a large number of people's expectations about how organizations should carry out their operations, one of them with social activities and corporate governance. Based on the results of these theoretical studies the following hypothesis can be formulated:

$\mathbf{H}_{2}$ : Corporate social responsibility disclosure will negatively affect the cost of equity capital for firms with good corporate governance.

\section{RESEARCH METHOD}

The research model is built on research as follows:

H1:

$$
\operatorname{CSR}_{\mathrm{i}, \mathrm{t}}=\mathrm{a}_{0}+\mathrm{a}_{1 C O C} \mathrm{it,-1}+\mathrm{a}_{2} \text { ROA }_{\mathrm{i}, \mathrm{t}-1}+\mathrm{a}_{3} \operatorname{SIZE}_{\mathrm{i}, \mathrm{t}-1}+\mathrm{a}_{4} \text { PBV }_{\mathrm{i}, \mathrm{t}-1}+\mathrm{a}_{5} \text { LEVERAGE }_{\mathrm{i}, \mathrm{t}-1}+\mathrm{a}_{6} \text { LIQUIDITY }_{\mathrm{i}, \mathrm{t}-1}+\mathrm{e}_{\mathrm{i}, \mathrm{t}}
$$

H2:

$$
\mathrm{COC}_{\mathrm{i}, \mathrm{t}-1}=\mathrm{b}_{0}+\mathrm{b}_{1} \mathrm{SIZE}_{\mathrm{i}, \mathrm{t}}+\mathrm{b}_{2} \text { BETA }_{\mathrm{i}, \mathrm{t}}+\mathrm{b}_{3} \text { LEVERAGE }_{\mathrm{i}, \mathrm{t}}+\mathrm{b}_{4} \mathrm{PBV}_{\mathrm{i}, \mathrm{t}}+\mathrm{b}_{5} \mathrm{CSR}^{*} \mathrm{CG}_{\mathrm{i}, \mathrm{t}}+\mathrm{e}_{\mathrm{i}, \mathrm{t}}
$$

As in Dhaliwal et al $(2011,2014)$, COC and CSR are endogenous variables as causality variables. Therefore the research model is as shown in model 1 and 2.

The research population is all public firms that are listed in the Indonesia Stock Exchange. The sample is determined by using a purposive sampling method: (1). Firms listed in the Indonesia Stock Exchange (IDX) in 2012 until 2014 (since the enactment of Government Regulation No. 47 of 2012 as the basis for the year of research and calculation of data $\mathrm{t}-1, \mathrm{t}$ and $\mathrm{t}+1$. (2). Firms present disclosure of corporate social responsibility in annual report or sustainability report according to research variables. Secondary research data used are financial and sustainability reports from 2012 to 2014. Sample data contains information on corporate social responsibility disclosure and corporate financial performance. The number of firms that is in accordance with GRI disclosure criteria for the content analysis CSR score calculation is 53 firms. There are 13 of firms with incomplete financial data in model 1 and 12 firms with incomplete financial data on model 2. There are 40 final sample firms for model 1 and 41 for model 2.

With respect to variable measurement, the independent variable is the Cost of Equity Capital (COC) with Ohlson Valuation $\mathrm{r}=(\mathrm{Bt}+\mathrm{Xt}+1-\mathrm{Pt}) / \mathrm{Pt}$ and the dependent variable is the disclosure of corporate social responsibility with CSR $=($ total score CSR / 58) $\times 100 \%$. The control variables are: Size $=$ natural logarithm of the firm's market value of equity; leverage $=$ long term debt: total assets, $\mathrm{PBV}=$ share price $/$ book value per share. Return on Assets $(\mathrm{ROA})=$ profit before income tax / total assets. Liquidity = total share tradedt / total outstanding sharet. Beta is calculated by return of stock $=\alpha+\beta$ market return (regression of stock return with market return) 
Moderation variables in this research is corporate governance / CG with CG index / score include: effectiveness of board of commissioner and audit committee effectiveness in monitoring of the company's operations

Data analysis using OLS multivariate analysis consists of: descriptive statistics, classical assumption test (multicollinearity and heteroscedasticity) and testing hypothesis. Multicollinearity testing based on tolerance and VIF values concludes that there is no multicollinearity in regression models 1 and 2. Scatter plots determine whether there is a pattern seen from the distribution of data. The pattern does not show indication heteroscedasticity (unstable).

\section{RESULTS AND DISCUSSIONS}

The results of the first hypothesis testing in table 1 show that the disclosure of corporate social responsibility in the previous year has a positive influence on the cost of equity capital in the coming year. This provides empirical support for the first hypothesis proposed in this study. Social responsibility practices will have an impact on the funding that must be spent to obtain further operational capital due to investor confidence in the firm's operational activities in the social/environmental field. Firm size control variables also have a significant positive effect on corporate social responsibility disclosure. Financial performance assisting the funding of the firm's operations. This has been done through corporate social responsibility. In agency theory, the disclosure of corporate social responsibility is one way to reduce agency conflict, resulting in reduced agency costs and information asymmetry. While in stakeholder theory claiming corporate social responsibility will satisfy interests of both shareholders and stakeholders. According to legitimacy theory, a firm will voluntarily report its activities if management believes that is what the community expects. The results of this study are consistent with previous studies ${ }^{2,5}$.

Table.1. Regression Results of First Hypothesis

\begin{tabular}{|c|c|c|c|}
\hline & $\begin{array}{c}\text { Sign } \\
\text { Expectation }\end{array}$ & Coefficient & Significant \\
\hline $\mathrm{COC}$ & + & 1.814 & $0.042 * *$ \\
\hline ROA & + & 0.155 & 0.340 \\
\hline Size & + & 0.644 & $0.015^{* *}$ \\
\hline PBV & - & -0.978 & 0.512 \\
\hline LEV & + & 0.095 & 0.981 \\
\hline \multicolumn{4}{|l|}{$\mathrm{Y}$} \\
\hline Constanta & $?$ & 0.266 & 0.979 \\
\hline \multicolumn{3}{|c|}{ Adjusted R-square } & 0.151 \\
\hline \multicolumn{3}{|c|}{ F-test Sign (F-statistic) } & $0.028 * *$ \\
\hline \multicolumn{3}{|l|}{$\mathrm{N}$} & 41 \\
\hline$* *$ Significe & at level 5\% & & \\
\hline
\end{tabular}

The $\mathrm{H} 2$ results in table 2 shows that corporate social responsibility disclosure in firms that have implemented good corporate governance have a lower cost of equity capital. Consequentially, the firm has carried out management responsibilities through corporate governance and its social responsibility. The existence of monitoring aspects of the board of commissioners and audit committee affects the firm's operational activities ability to have more responsibility on the external side of the firm. If a firm practices social responsibility and corporate governance, there will be an impact on the funding that must be spent by the firm to obtain further operational capital through investors' confidence in the firm's operational activities in the social/environmental field. The leverage control variable also has a significant positive effect on corporate social responsibility disclosure. It shows that firms using funding sources will increase potential returns for shareholders, through corporate social responsibility and corporate governance mechanisms.

In agency theory, corporate social responsibility disclosure and corporate governance mechanisms are one way to reduce agency conflicts, resulting in reduced agency costs and information asymmetry. In other words, investors or shareholders see the firm's openness in managing its funds, which increase trust and profit for investors or shareholders. Based on stakeholder theory, the interest in corporate social responsibility and corporate governance is relevant to shareholder and stakeholder interests. According to the theory of legitimacy, a firm will voluntarily report its activities if management considers it to be what the community hopes for, especially firms with good governance practices. This is reflected in the existence of a social contract between the firm and the society in which it operates and it has been regulated by corporate of social responsibility disclosure and demands for corporate governance by the public. Results of this study are in line with previous studies ${ }^{3}$ which partially tested that corporate governance structure positively affects corporate social responsibility and corporate social 
responsibility negatively impacts the cost of equity capital ${ }^{28}$.

Table.2. Regression Results of Second Hypothesis

\begin{tabular}{lccc}
\hline & $\begin{array}{c}\text { Sign } \\
\text { Expectation }\end{array}$ & Coefficient & Significant \\
\hline CSR & $\infty$ & $\infty$ & $\infty$ \\
Size & + & 0.076 & 0.317 \\
BETA & + & 0.035 & 0.829 \\
LEV & + & 1.370 & $0.038^{* *}$ \\
PBV & - & -1.21 & 0.699 \\
CSR*CG & - & -0.75 & $0.047^{* *}$ \\
Constanta & $?$ & -1.263 & 0.460 \\
Adjusted R-square & & 0.139 \\
F-test Sign (F-statistic) & & 0.41 \\
N & & 40 \\
\hline ** Significant at level 5\% & & \\
\hline
\end{tabular}

\section{CONCLUSION}

The purpose this study was to examine whether the influence of corporate of social responsibility disclosure positively affects the cost of equity capital in the previous year and test whether the disclosure of social responsibility negatively affects the cost of equity capital in firms with good corporate governance. The results of this study provided empirical evidence to corroborate both hypotheses. This study found that the influence of corporate of social responsibility disclosure positively related to cost of equity capital in the previous year and disclosure of social responsibility negatively affects the cost of equity capital in firms with good corporate governance.

Limitations of this study need to be put forward so that the interpretation of results can be qualified. Understanding research limitations aid the development of similar research in the future. Limitations are as follows: (1). The firm sample is small, which means the social responsibility of score measurements for this research is based on social responsibility disclosure, which, according to GRI 4, would be different if is done by content analysis with other provisions such as KLD Research and analysis checklist or use of dummy variable. (2). Following the research model of Dhaliwal et al. (2011, 2014), the study period (2012 to 2014) is only two years, which therefore raises limitations concerning the generalization of research results.

\section{ACKNOWLEDGMENTS}

The content of this paper has received input from International Accounting Conference (IAC) reviewer, Sylvia Veronica and Ratna Wardhani as lecturers. This paper has been presented at the $6^{\text {th }}$ IAC Department of Accounting Faculty of Economics and Business, Universitas Indonesia 2017 in Yogyakarta Indonesia.

\section{REFERENCES}

[1] S. Arta, R. N. S. Ananda, S. Enni. Faktor-faktor yang mempengatuhi luas pengungkapan informasi lingkungan perusahaan berbasis website (studi empiris pada industri rawan lingkungan yang terdaftar di BEI tahun 2013), Simposium Nasional Akuntansi XVIII, Medan, (2015).

[2] D. S. Dhaliwal, O. Z. Li, A. Tsang and Y. G. Yang. Voluntary nonfinancial disclosure and the cost of equity capital: the initiation of corporate social responsibility reporting, The Accounting Review, 86(1), (2011) 59-100.

[3] D. S. Dhaliwal, O. Z. Li, A. Tsang and Y. G. Yang. CSR disclosure and the cost of equity capital: the roles of stakeholder orientation and financial transparency, Journal Accounting Public Policy, 33 (2014) 328-355.

[4] L. Chen, A. Feldman and O. Tang. The relationship between disclosure of corporate social performance and financial performance: evidence from GRI reports in manufacturing industry, International Journal Production Economics, 170 (2015) 445-456.

[5] C. A. Botosan. Disclosure level and the ccost of equity capital, The Accounting Review,72 (1997) 323-349.

[6] M. Lang and R. Lundholm. Cross-sectional determinants of analyst ratings of corporate disclosures, Journal of Accounting Research, 31 (1993) 246-271.

[7] S. El Ghoul, O. Guedhami, C. Y. Kwok, and D. Mishra. Does corporate social responsibility affect the cost of capital?, Journal Bank Finance, 35(9) (2011) 2388-2406.

[8] J. R. Francis, I. K. Khurana, R. Pereira. Disclosure incentives and effects on cost of capital around the world, The Accounting Review, 80 (2005) 125-1162.

[9] KPMG. The KPMG survey of corporate responsibility reporting 2013. Retrieved from http://www.kpmg.com (2013).

[10] M. C. Jensen and W. H. Meckling. Theory of the firm: managerial behavior, agency costs, and ownership structure, Journal of Financial Economics, 3 (1976) $305-360$.

[11] W. R. Scott. Financial accounting theory $4^{\text {th }}$ edition. Prentice Hall, Upper Saddle River (2009).

[12] R. Gray, R. Kouhy, and S. Lavers. Corporate social and environmental reporting: a review of the literature and a longitudinal study 
of UK disclosure, Accounting, Auditing \& Accountability Journal, 8(2) (1995) 47-77.

[13] E. E. Ten. Applying stakeholder theory to analyze corporate environmental performance, evidence from Australian listed firms, Asian Review of Accounting, 15(2) (2007)164-184.

[14] C. Deegan, C. The legitimising effect of social and environmental disclosures - a theoretical foundation, Accounting, Auditing \& Accountability Journal, 15(3) (2002) 282-311.

[15] J. Guthrie and I. Abeysekera. Content analysis of social, environmental reporting: what is new?, Journal of Human Resource Costing \& Accounting, 10(2) (2006) 114-126.

[16] S. Kastutisari and N. H. U. Dewi. Pengaruh pengungkapan corporate social responsibility (CSR) terhadap abnormal return. Retrieved from http://ojs.unud.ac.id/ (2016).

[17] A. Lako. Dekonstruksi CSR dan reformasi paradigma bisnis dan akuntansi, Erlangga, Jakarta (2010).

[18] A. A. Mardiyah. Pengaruh informasi asimetri dan disclosure terhadap cost equity of capital, Jurnal Riset Akuntansi Indonesia, 5(2) (2002) 229-256.

[19] M. Mangena, R. Pike, and J. Li. Intellectual capital disclosure practises and effects on the cost of equity capital. UK evidence, The Institute of Chartered Accountants of Scotland, University of Bradford, Bradford (2010).

[20] A. Shleifer and R. A. Vishny. A survey of corporate governance, Journal of Finance, 52 (1997) 737-783.

[21] E. F. Fama and M. C. Jensen. Separation of ownership and control, Journal of Law and Economics, 24 (1983) 301-325.

[22] M. A. Desai and D. Dharmapala. Corporate tax avoidance and firms value, The Review of Economics and Statistics, 91(3) (2009) 537-546.

[23] N. S. A. Wahab and K. Holland. Tax planning, corporate governance dan equity value, The British Accounting Review, 44(2012) 111-124.

[24] S. Chen, X. Chen, Q. Cheng, and T. J. Shevlin. Are family more tax aggressive than non-family firms?. Journal of Financial Economics, 95(1) (2010) 1- 48.

[25] A. A. Hermawan. Pengaruh efektifitas dewan komisaris dan komite audit, kepemilikan oleh keluarga, dan peran monitoring bank terhadap kandungan informasi laba, Dissertasion, Universitas Indonesia (2009).

[26] C. A. Botosan. Disclosure and the cost of capital: what do we know?, Account. Business Res. Int. Account. Policy Forum, (2006) 3140.

[27] D. S. Dhaliwal, S. Radhakrishnan, A. Tsang and Y. G. Yang. nonfinancial disclosure and analyst forecast accuracy: international evidence on corporate social responsibility disclosure, The Accounting Review, 87(3) (2012) 723-759.

[28] R. P. M. Siregar. Analisis pengaruh struktur corporate governance terhadap corporate social responsibility disclosure dan implikasinya terhadap cost equity capital, Undergraduate Thesis, Faculty of Economics and Business, Universitas Diponegoro (2013). 